\title{
10
}

\section{Mapping legal change in the context of reforms to Chinese police powers}

\author{
Sarah Biddulph
}

In 1978, the Central Committee of the Communist Party of China (CPC) began a program of economic modernisation and reform, ${ }^{1}$ a core aim of which was rebuilding the Chinese legal system. ${ }^{2}$ The importance of this aim increased further in 1996, when the Party approved the program of 'ruling the country according to law' (yifa zhiguo). In a speech in 1996 and in his subsequent keynote address to the Fifteenth National Congress of the CPC in September 1997, Jiang Zemin advocated 'Us(ing) law to rule the country, protect the long-term peace and good order of the state (yifa zhiguo, baozhan guojia changzhi jiu'an)'. ${ }^{3}$ Subsequently, the Party adopted the slogan that 'ruling the country on the basis of law is the basic program by which the Party leads the people in ruling the country' (Zhu Rongji 1999:2). An increasingly important component of 'ruling the country according to law' has been a requirement that law provide the foundation on which state power is defined and exercised. That is, implementation of a system of law-based governance. The desire for formal legal legitimation of the exercise of the state's administrative power is captured in the slogan 'administration according to law' (yifa xingzheng). ${ }^{4}$

The process of constructing the legal system has, accurately, been described as 'an event of epic historic proportions' (Alford 1999:193). While reforms to the legal regulation of economic relations have taken place at a phenomenal rate, this chapter focuses on the slower, and arguably more complex, process of reforming state administrative powers, specifically one of the administrative detention powers of the Chinese public security organs (gong'an jiguan, also referred to in this chapter as the 'police' $)^{5}$-detention for investigation (shourong shencha). ${ }^{6}$ This power is particularly interesting because it was ostensibly abolished by amendments to the Criminal Procedure Law in 1996. 


\section{DESCRIBING THE PROCESSES OF LEGAL REFORM: THE PROBLEM STATED}

Why choose to examine this power? My concern with the police and their detention powers in particular, lies in the slowness, complexity and unevenness of the legal reforms in this area. Scholars and human rights organisations agree that the reforms to the sanctioning system, including criminal and administrative sanctions, have not been as effective as in other areas of Chinese law. ${ }^{7}$ One scholar has commented that legal reforms in different sectors may 'be out of synchrony and in conflict with each other' (Winkler 1999:3). In attempting to describe the story of China's legal modernisation in areas such as police power, we must find a way to engage with the internal diversity, even inconsistency, in the ways in which legal reform is given substance and implemented across different sectors.

There are many different ways to approach a study of legal reform. The analytical framework brought to bear will influence not only the questions posed, but also our understanding of the answers to those questions. Even if we are content with a purely descriptive framework, the very act of selecting what to describe involves a choice about what we consider to be relevant or important. Arguably, pure description thus also reflects some paradigm, even if that paradigm is not articulated.

One influential paradigm for evaluating legal reform since the beginning of the reform era ${ }^{8}$ has been to trace the strengthening and entrenchment of formal, bureaucratic, or judicial modes of justice under the rubric of socialist legality against a weakening of the informal modes of justice that predominated in revolutionary periods (Baum 1986; Brugger and Reglar 1994; Dreyer 1996). When plotted against the criteria of formal and informal modes of justice, the ongoing use of administrative forms of detention suggests that informal administration of justice persists.

As legal reform has progressed, many studies have focused on whether reforms to China's legal system indicate a transition from an instrumentalist vision of rule by law toward some version of the rule of law. ${ }^{9}$ Randall Peerenboom, for example, concludes that the Chinese legal system is moving towards, but has not yet achieved, a formalist rule of law. Nonetheless, he argues it is no longer apposite to characterise the Chinese legal system as rule by law. ${ }^{10} \mathrm{He}$ argues that many areas of the Chinese legal system, including the administrative law system, have, over the last 20 years, shown signs of convergence with Western legal systems (Peerenboom 2002a). As this trend continues, it is likely that the Chinese system will develop traits in common with the legal systems of industrial countries (Peerenboom 1999, 2002b). Seen in this way, legal reform of the state's coercive powers for crime control and social order appears to have 'lagged' behind that of other sectors. Many scholars argue that, despite legal reforms, the state's sanctioning system remains an instrument of social and political control (Potter 1999; Lubman 1999). ${ }^{11}$ Viewed within the paradigm of transition towards a system of the rule of law, the continuing use of administrative forms of detention and hard strikes against crime has been characterised as a form of 'pernicious instrumentalism' (Peerenboom 1999:327-8). 
Closely aligned to this model of the transition to the rule of law is consideration of the extent to which China's legal system is becoming 'modern'. The work of Weber ${ }^{12}$ is considered by many as the yardstick of whether a 'modern' criminal justice system is being created (Tanner 1999). Scholars such as Ma and Wong have noted that reforms in the structure and powers of the Chinese police have been the catalyst for the creation of a professional and 'modern' police force. ${ }^{13}$ Others conclude that the Chinese police have become an 'institutional hybrid', pointing to the coexistence of Maoist strategies of mass campaigns and the retention of 'such mainstream Stalinist institutions as labour camps', with a 'groping toward more modern forms of police work... based on legal institutions and professional training' (Winkler 1999:16-7).

These models for understanding legal change focus our attention on the extent to which reforms have progressed towards embracing either a formal system of justice, the rule of law, or modernity. They highlight the continuing influence of earlier, revolutionary modes of justice on current reform processes by focusing our attention on the outcomes of current reform measured against some standard. ${ }^{14}$

In this chapter, I will outline an alternative approach that focuses more on the processes of change than on its outcomes. This approach adopts the hypothesis that legal change is a structured yet contested process with an unknown endpoint. To do this, I will draw on a version of Bourdieu's concept of the legal field, applied in the context of rapid change currently taking place in China.

\section{THE ANALYTICAL FRAMEWORK INTRODUCED: THE LEGAL FIELD}

According to Bourdieu, a society comprises a 'series of interrelated yet semiautonomous fields, each of which has a distinct structure' (Trubek et al. 1994:414). Each field may be divided into subfields, each of which has its own particular logic and rules (Bourdieu and Wacquant 1992).

A field is described as 'an area of structured, socially patterned activity or "practice" in this case (that is, the legal field) disciplinarily and professionally defined' (Terdiman 1987:805-6) and a 'network...of objective relations between positions' (Bourdieu and Wacquant 1992:97). The legal field is 'organised around a body of internal protocols and assumptions, characteristic behaviours and self sustaining values'.$^{15}$ Each field has its own logic that is 'specific and irreducible to those that regulate other fields' (Bourdieu and Wacquant 1992:97). ${ }^{16}$

Bourdieu draws an analogy between the legal field and a 'game', such as a game of tennis (Bourdieu and Wacquant 1992). The legal field is constituted by the ongoing struggle or competition between different legal actors to 'appropriate the specific products' (Bourdieu 1987:818; Bourdieu and Wacquant 1992), or stakes, of the field-money, status, power (Trubek et al. 1994) ${ }^{17}$ and what Bourdieu describes as the 'right to determine the law' (Bourdieu 1987:816, 817). ${ }^{18}$ 
Whilst the players compete with each other for the stakes of the game, they all concur in their belief that both the game itself and the stakes of the game are worth competing for and vie with each other on the basis of the 'rules of the game' (Bourdieu and Wacquant 1992:98). ${ }^{19}$ Using the analogy of a tennis game, the net and the lines on the tennis court mark out the parameters within which these contests take place. Legal actors share a legal 'habitus', which is the shared practices, views, values and dispositions of actors, and what Terdiman describes as the 'habitual ways of understanding, judging and acting ${ }^{\prime 2} .^{20}$

In China, the process of reconstructing the legal system is just over twenty years old. During the revolutionary era of CPC governance prior to 1978, efforts were made to obliterate the distinctive vocabulary and logic of the law and to displace legal institutions and actors in favour of political ones. The CPC's decision to rebuild the legal system has created conditions conducive to the emergence of a distinctive legal field. Rather than assume the existence of an established, relatively autonomous legal field, the search in China is to trace the emergence of a legal field - that is, to identify legal actors, a distinctly legal habitus, rules of the game and stakes over which actors compete.

The basic requirement that administration be carried out according to law has placed the Party's authority behind the process of legalisation of the administrative agencies' powers, requiring that powers now be justified in legal, rather than political terms. While the impetus for the emergence of the legal field derives from Party policy and Party leadership, it is not inevitable that the Party controls all the contests that take place within the field. Arguably, the policies of rule according to law and administration according to law are sufficiently flexible to permit adoption of a range of legitimate positions about the meaning and scope of these policies. ${ }^{21}$

The boundaries of the field, according to Bourdieu, are themselves porous and constantly being negotiated - the 'stakes of the struggles' that take place within the field itself (Bourdieu and Wacquant 1992; Trubek et al. 1994). The competition between legal actors helps to define the scope of the legal field itself (Terdiman 1987). The logic and rules of the legal field are created as a result of this competition and not because of some immutable development toward a pre-ordained point (Bourdieu and Wacquant 1992).

The building of law in China has promoted the emergence of a range of legal actors, whose professional qualifications now distinguish them from lay people. This has been facilitated by the program of legal institution building in China, which has imposed increasingly onerous qualification criteria on admission to be, for example, a lawyer or a judge.

The use of specialised legal language and reasoning help define the legal field's boundaries and degree of autonomy by requiring that disputes be reconstructed in legal terms and that they be resolved in accordance with the 'rules and conventions of the field itself' (Bourdieu 1987:831). Thus, for conflicts between parties to be resolved legally, they must first be redefined or, as Bourdieu (1987) puts it, 
retranslated, in legal terms before being submitted for resolution in accordance with legal rules and procedures. The expansion of the field takes place as matters previously defined and exercised in a non-legal way are redefined in legal terms and brought within the legal field ('appropriative constitution') (Bourdieu 1987).

The ongoing conflict over competence and status between legal actors results in the creation of a hierarchy amongst legal actors (Bourdieu 1987; Terdiman 1987), which is itself susceptible to change over time (Bourdieu 1987). This conflict, according to Bourdieu, determines which actors are authorised to make legitimate interpretations of legal texts and legal practice (Bourdieu 1987; Terdiman 1987). Changes in this hierarchy of privilege and authority reflect the changing political status of groups (Bourdieu 1987). Although some actors may dominate the field and 'are in a position to make it function to their own advantage...they must always contend with the resistance, the claims, the contention, political or otherwise, of the dominated' (Bourdieu and Wacquant 1992:102). Law is produced as an outcome of this competition.

An examination of the reforms to the administrative power of detention for investigation carried out in terms of the legal field raises a number of questions. Is there an emerging legal space in which a range of actors may adopt diverging positions, while at the same time agreeing on the basic parameters within which these positions are to be contested? Are the terms of the debate identifiably legal, using specialist legal vocabulary and legal reasoning? Is there sufficient force or attraction of this field, in terms of legitimation or some other stakes, to reconfigure a debate, which might otherwise have been conceived in political terms, into one framed in terms of legality?

\section{THE POLICE AS LEGAL ACTORS}

Of relevance to a discussion about police powers is the role of the police in legal debates. I argue that it is possible to define the police as legal actors and to see the police force itself as constituting a semi-autonomous social field ${ }^{22}$ that intersects with the legal field. The police are both influenced by, and influence, debates in the legal field and the state's legal order.

Alongside the reconstruction of the legal system, since 1978, the police have been required to transform themselves from a revolutionary force into a security force responsible for the management of public order and control of crime (Dutton 2000; Fu Hualing 1994). Prior to 1979, their primary task was the violent suppression of class enemies. During what was seen as the revolutionary stage of establishment of the PRC, the police constituted one of the main politico-legal organs of the state, responsible for development and protection of the people's democratic dictatorship (Cui Ming 1993a; Zhengci Falu Jiaoyanshi 1983). In their own words, the public security organs were a 'sharpened weapon for suppression of class enemies' (von Senger 1985:172; see also Wang Fang 1993). ${ }^{23}$ 
The task of reconstructing the public security organs began with decisions to revive the criminal investigation division to strengthen local-level public order work (Xi Guoguang and Yu Lei 1996) and revive the local-level organisations involved in that work, including residents' committees, mediation committees and security defence committees (Peng Zhen 1982). In April 1983, the Central Committee of CPC approved a decision of its Central Political-Legal Committee to undertake a systematic and comprehensive reform of the public security organs, including strengthening the legal basis of police organisation and powers. ${ }^{24}$

Since then, police reforms have gradually created a more professional force (Dutton 2000; Ward and Bracey 1985), with greater emphasis placed on the education and specialist technical training of police officers ${ }^{25}$ and the legalisation of police powers (Shen Zhongmin and Xu Zhenqiang 1997). Although the process of legalisation of police powers is incomplete in many respects, ${ }^{26}$ scholars such as Ma point to laws such as the 1995 People's Police Law (PPL) as being significant in 'China's efforts to create a more professional and modern police force' (Ma Yue 1997:113). Kam Wong (2002:294) asserts that the introduction of a system of police ranks has 'regularised, rationalised and legalised the police along Weberian lines'.

Fu Hualing's work also suggests that it is no longer appropriate to assume that the police are an unreflexive enforcement arm of the Party; instead, the police have their own distinct institutional interests. Fu (1994) suggests that, along with their transformation to a more regular security force, the police have lost their privileged position with the CPC vis-à-vis other government departments.

Viewed as a semi-autonomous social field, the police can be seen as having a multifaceted relationship with law. They have a vested interest in participating in the contests in which their powers are legally defined, most notably in areas where the principles of law enforcement are established and systems of accountability for the exercise of police power are set up.

\section{THE EXAMPLE OF ABOLITION OF DETENTION FOR INVESTIGATION}

\section{Development of detention for investigation from the 1950s}

Detention for investigation (shourong shencha) developed out of the CPC's efforts to restore social order after it took power in 1949. The power of detention for investigation was adopted by the CPC Central Committee (the 'Central Committee'), and the State Council, at the end of 1957, to deal with the problem of unauthorised rural migration (Central Committee 1957; Zhang Qingwu 1990). It was used initially primarily to detain and repatriate rural migrants, as well as to investigate suspected criminal activities (Zhang Qingwu 1990). In response to the social upheaval caused by the famine resulting from the Great Leap Forward (Spence 1990), in 1961, the Central Committee approved the creation of 'detention for repatriation stations'. 
These stations were used for the detention and repatriation of rural migrants who had floated to the cities and for the investigation of those suspected of criminal or counter-revolutionary offences (Central Committee 1961; Fan Chongyi and Xiao Shengxi 1991; Cui Ming 1993b). At this time, the official purpose of the power was 'primarily to rescue, educate and help settle down people who had floated to the city as beggars and to protect social order' (Wang Jiancheng 1992:179).

Towards the end of the Cultural Revolution in 1975, the use of detention for investigation of suspected criminal conduct by transients was separated from the detention for repatriation of unauthorised rural migrants (Fan Chongyi and Xiao Shengxi 1991). The police were given responsibility for managing the detention and investigation of those suspected of criminal conduct, while the civil administration organs ran the stations responsible for repatriation of rural migrants (Fan Chongyi and Xiao Shengxi 1991). In 1980, at the beginning of the reform era, the Central Committee and the State Council jointly issued a report prepared by the Ministry of Public Security which provided for the gradual absorption of detention for investigation into Re-education Through Labour (RETL), where investigations of suspected criminal activity were to be carried out. ${ }^{27}$ At that time, legislative drafters declined to include detention for investigation within the scope of the Criminal Procedure Law. Instead, the Criminal Procedure Law provided the police with a more restrictive power to detain for interrogation a person suspected of committing a crime, which was limited to 10 days. ${ }^{28}$

Before detention for investigation could be incorporated within RETL, in August 1983 the Party launched the first campaign of the Hard Strike Against Serious Crime (Fan Chongyi and Xiao Shengxi 1991; Cui Ming 1993b). Not only was the work of integrating detention for investigation with RETL halted, but the use of detention for investigation expanded dramatically. ${ }^{29}$ As one senior academic noted at the time, 'detention for investigation centres became large storehouses for detaining all types of offenders' (Cui Ming 1993b:92).

After this time, detention for investigation became a tool used by the police to detain for interrogation a wide range of people suspected of committing crimes. The time limits imposed for detention for investigation were considerably longer than the criminal detention power authorised under the Criminal Procedure Law (CPL). ${ }^{30}$ Not surprisingly, the power was used as a substitute for criminal detention and investigation and for a range of other purposes (Liu Huayin and Liu Baiyang 1992; Zhang Shanyu and Zhang Shuyi 1991). ${ }^{31}$

\section{The problems with detention for investigation}

Detention for investigation was described as the 'longstanding difficult problem' (laodanan wenti) between construction of a socialist legal system and enforcement practice (Liu Shipu 1990:22). It was a power essentially without any formal legal basis. From 1985, the Ministry of Public Security (MPS) issued a range of official documents that sought to define the targets, time limits, and procedures for imposing detention as a means of curbing the rampant abuse of this power. ${ }^{32}$ 
In 1987 the MPS described the power as

.... a type of coercive administrative investigation measure used by public security organs in accordance with State Council regulations against those who are suspected of roaming around committing offences, or have committed a criminal act and do not tell their correct name and address and whose background is not clear. It is not a type of criminal punishment, nor is it a public order administrative punishment. ${ }^{33}$

By 1987, local public security organs had been repeatedly criticised by the MPS for abusing their powers of detention for investigation. ${ }^{34}$ The MPS continued to exhort local public security organs to curb abuse of the power, and even suggested that the power itself might be lost should the abuses continue unabated.$^{35}$

In 1987, the MPS issued a notice that criticised the continuing abusive practices under this powerbut at the same time sought to limit the public outcry against abuse of the power by restricting disclosure or public discussion of the power. It was argued that public and media discussions of the use of detention for investigation in handling criminal investigations had led to 'misunderstandings' and 'bad impressions'. ${ }^{36}$

The continuing problems of serious abuse led to increasing public dissatisfaction and concern at senior political levels (Wong 1996), in turn prompting increased scrutiny by state organs outside the public security sector. Amongst the numerous notices demanding that abuses of the power be curbed, ${ }^{37}$ the MPS indicated that abuses of detention for investigation had been the subject of complaints and investigation by people's congresses at both local and national levels. ${ }^{38}$

\section{Finding a legal basis for detention for investigation}

While seeking to curb abuse and deal with the growing criticism of police misconduct, the MPS was also trying to address the criticisms that there remained no clear legal basis for the power. The clearest legal basis of the power had been provided by the Notice issued by the State Council on 29 February 1980 titled On Supporting the Unification of the Two Measures of Forced Labour and Detention for Investigation with RETL. Although this notice sets out the scope of targets for detention for investigation, ${ }^{39}$ it was unsatisfactory as a legal basis for the power in several respects, ${ }^{40}$ most notably because the main purpose of the notice-to merge detention for investigation with RETL—was never carried out. ${ }^{41}$ Further, this notice did not clarify the relationship between detention for investigation and other police powers to detain and interrogate criminal suspects set out in the Criminal Procedure Law, nor did it clarify its relationship to administrative sanctions for minor public order infringements that could be punished under the Security Administrative Punishment Regulations (SAPR). ${ }^{42}$ The MPS sought to supplement this document by providing a more detailed directive setting out targets and procedures for exercising the power in the 1985 MPS Notice on Strictly Controlling the Use of Detention for Investigation Measures.

By requiring the MPS to draft a Detention for Investigation Law (Shourong Shencha $\mathrm{Fa}$ ) in May 1983, the Central Committee of the CPC made it clear that detention for 
investigation required a legislative basis and that it be subject to strengthened legal supervision (Central Committee 1983; Gao Xianduan 1990). However, the MPS failed in its bid to have its draft legislation placed on the legislative plan of the National People's Congress Standing Committee and enacted as legislation because of its inability to obtain consensus on the major issues (Gao Xianduan 1990; Guo Dawei 1990).

Passage of the Administrative Litigation Law (ALL), which came into effect on 1 October 1990, increased the urgency of finding a legislative basis for detention for investigation. ${ }^{43}$ The Administrative Litigation Law empowered the courts to determine the legality of certain categories of administrative decision-making, including those dealing with the imposition of detention ${ }^{44}$ and coercive measures against the person and property. ${ }^{45}$ Under the Administrative Litigation Law, the administrative agency was obliged to prove the lawfulness of the conduct, at least requiring the police to point to conformity of the detention with laws and regulations which, together, constituted the 'legal basis' of the power. ${ }^{46}$ There was some ambiguity about whether detention for investigation should be seen as an administrative act and so whether it fell within the scope of the Administrative Litigation Law. That question was resolved in the Opinion of the Supreme People's Court Concerning Several Questions on the Implementation of the 'PRC Administrative Litigation

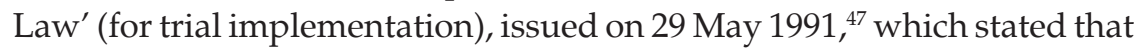

[t]he scope of accepting cases at Article 11 of the ALL...citizens who are dissatisfied with the decision of a public security organ for coercive detention for investigation, can commence litigation in the people's courts. ${ }^{48}$

The MPS then outlined criteria on which the lawfulness of detention for investigation would be determined in the Notice on Several Questions about the Implementation by Public Security Organs of the 'Administrative Litigation Law'. ${ }^{9}$ The question of whether the MPS was authorised at all to specify the documents constituting the legal basis of the powers it exercised was ignored.

\section{DEBATES ABOUT REFORM OR ABOLITION OF DETENTION FOR INVESTIGATION}

Despite the MPS's efforts to stifle public discussion of detention for investigation, in the late $1980 \mathrm{~s}^{50}$ and early 1990s, debate about the possible reform of detention for investigation began appearing in law and police journals, and became incorporated in broader discussions about reform of the Criminal Procedure Law (Zhongguo Faxue Hui Susong Fa Yanjiu Hui 1992; Fan Chongyi and Xiao Shengxi 1991; Wang Jiancheng 1992). ${ }^{51}$ A number of proposals for reform of detention for investigation emerged. These included passing sui generis legislation either by the NPC or administrative regulations by the State Council, incorporating the substance of the power into the revised Criminal Procedure Law, or merging the power with RETL (Gao Xianduan 1990; Fan Chongyi and Xiao Shengxi 1991). 
Many legal academics and some representatives of people's congresses, and one legal academic in the public security system in particular, argued that the power should be abolished as it was both arbitrary and illegal (Cui Ming 1993b). ${ }^{52}$ The arguments were framed in both legal and practical terms. There were a number of aspects to the legal arguments, with the overarching premise resting on assertions that the power's existence was unconstitutional. First, it was argued that the power was contrary to the spirit of Article 37 of the Constitution, which guarantees freedom of the person unless lawfully arrested (Cui Ming 1993b; Wang Xixin 1993). A second argument was that the State Council was not competent to pass laws authorising detention. ${ }^{53}$ Third, it was noted that the power to detain administratively undermined the integrity of the criminal procedure system as it was, in practice, a substitute for criminal detention, but was outside the Criminal Procedure Law (Cui Ming 1993b).

On a practical level, it was argued that the power was ineffective in the investigation of crimes (Zhang Jianwei and Li Zhongcheng 1994), and that reform would not solve the problem of abuse (Cui Ming 1993b). There was common recognition that the power was used as a substitute for criminal detention and other criminal coercive powers (Li Huayin and Liu Baiyang 1992; Zhang Shanyu and Zhang Shuyi 1991; Gu Haiwen 1992).

Police, government officials ${ }^{54}$ and academics who argued for retention of the power agreed that reform was needed to rectify its inadequate legal and regulatory basis, but they also noted that it was very effective in practice (Li Huayin and Liu Baiyang 1992; Gao Chuanli 1990; Fan Chongyi and Xiao Shengyi 1991; Chen Weidong and Zhang Tao 1992b; Wang Jiangcheng 1992; Jiang Bo and Zhan Zhongle 1994) and accorded with the 'national spirit' (Chen Weidong and Zhang Tao 1992b:172). Views differed amongst academics discussing revisions to the Criminal Procedure Law about whether detention for investigation should be included as a criminal coercive measure..$^{55}$

Central to the debates about reform or abolition of detention for investigation was the question of whether the power should be characterised as administrative or criminal in nature. ${ }^{56}$ On one hand, the question had already been answered by the Supreme People's Court's interpretation of the scope of the Administrative Litigation Law. ${ }^{57}$ This was subsequently acted upon by the MPS in its specification of the documents constituting the legal basis for judging the lawfulness of any act of detention under the Administrative Litigation Law. ${ }^{58}$ Nonetheless, as part of the debate about reform or abolition of the power, its proper legal characterisation remained an important issue.

The discussions about the fate of detention for investigation became subsumed within the debates about reform of the Criminal Procedure Law after a group of legal academics was appointed to prepare a discussion draft, published in 1995, of amendments to the Criminal Procedure Law (Chen and Yan 1995). The paper advocated the abolition of detention for investigation (Chen and Yan 1995), despite the obvious inconvenience to the police this would cause (Chen and Yan 1995:205-6). 
As compensation, they suggested that the standard of evidence required to approve arrest be lowered to 'where there is evidence to support a strong suspicion that a crime has been committed where the criminal suspect could be sentenced to punishment of no less than imprisonment' (Chen and Yan 1995:22). ${ }^{59}$ The drafting group considered that, even though detention for investigation was to be abolished, it was inappropriate to lengthen the time limit for detention of a maximum of 10 days set out under the 1979 Criminal Procedure Law. ${ }^{60}$

In the meetings that were held after publication of the draft discussion paper, attended by interested state organs, the MPS turned its attention to negotiating inclusion of substantive elements of the power of detention for investigation into the amended Criminal Procedure Law. ${ }^{61}$ Proposals included decreasing the standard of evidence required for arrest ${ }^{62}$ and expanding the scope of targets and time permitted for detention to include those who previously fell within the scope of detention for investigation. ${ }^{63}$ It was further suggested that, in cases where suspects withheld their real names and addresses, the calculation of time in detention would not commence until the suspect's name, address and background had been clarified. ${ }^{64}$

\section{Incorporation of detention for investigation into the amended Criminal Procedure Law and ongoing interpretations}

In his explanatory speech on the draft amended Criminal Procedure Law to the Fourth National Peoples' Congress Meeting on 12 March 1996, Gu Angran proclaimed the abolition of detention for investigation, stating

[d]etention for investigation is a type of administrative coercive measure that has been of positive use for clarifying and investigating crime, especially for investigating those who float from place to place-committing crime and whose identity is not clear. But, the time of detention in detention for investigation is comparatively long. Moreover, because it doesn't involve any other judicial organ and the decision is made by the public security alone, it lacks a system for supervision and restriction and does not conform to the relevant requirements of the CPL.

In order gradually to strengthen socialist democracy and legal system construction, better to protect the rights and interests of citizens, we have absorbed the contents of detention for investigation needed in practice for the struggle against crime into the CPL by supplementing and amending the relevant criminal coercive measures and have not retained the administrative coercive measure of detention for investigation.

In the final version of the Criminal Procedure Law passed by the National People's Congress, the public security organs had managed to claw back more power than the discussion draft would have allowed, in effect to incorporate many aspects of detention for investigation into the Criminal Procedure Law. The standard for approval of arrest had been further reduced to where 'the principal facts of the crimes have been clarified and [the criminal suspect] could be sentenced to a term of not less than imprisonment'. ${ }^{65}$ The scope of targets for detention was expanded to include targets of the former detention for investigation where 'there is a strong suspicion that the person goes from place to place committing crimes, who repeatedly commits crimes, or who gangs up with others to commit crime'.66 The time limits for 
requesting arrest of certain categories of detainees, including some previous targets of detention for investigation, ${ }^{67}$ was increased from a maximum of seven days to 37 days. $^{68}$

After passage of the amended Criminal Procedure Law, a police commentator suggested that, in theory, the broadening of coercive powers in that law provided the public security organs with sufficient power to perform their criminal investigation functions and to compensate for their loss of detention for investigation (Cui Xin 1996). The amendments, this author suggested, required the public security organs to 'change their traditional work style' from an emphasis on obtaining evidence through interrogation of detained suspects to a broader range of investigation techniques and competencies (Cui Xin 1996:36-7). Changing the police work style and improving their technical investigation skills may be difficult. ${ }^{69}$

Of course, passage of the amended Criminal Procedure Law did not end the ongoing process of construction and reconstruction of police detention powers. After passage of the Criminal Procedure Law, the MPS issued a notice interpreting police-related provisions of the Criminal Procedure Law, which further expanded the calculation of the time limits for detention of criminal suspects who were targets of the former detention for investigation. ${ }^{70}$ In particular, the interpretation asserted the requirement that the time limits for detention not commence until there was clarification of the name, address and background of the detainee. Article 28 of the Criminal Procedure Law permits the 'investigation and detention period' (zhencha jiya qixian) for those 'who do not tell their true name and address or whose identity is unclear' to commence from the date their identity is clarified. Article 112 of the MPS's interpretation document explained the scope of Article 128 of the Criminal Procedure Law as follows

\footnotetext{
Criminal suspects who do not tell their true name and address, whose identity is not clear, if it has not been possible to clarify these matters and to apply for arrest within thirty days, after receipt of approval from the responsible person in the public security bureau at county level or above, the time period for detention will commence from the date on which the identity of the person is clarified, but it is not permitted to halt the investigation into their criminal actions.
}

One academic claims the original intent of Article 128 of the Criminal Procedure Law was to permit extension of the period of detention after, rather than prior to, the arrest, and that in no circumstances could the period of pre-arrest criminal detention be extended past a total of 37 days (Wang Jiancheng 2000). The commentator suggests that such an interpretation should be abolished, otherwise 'it would be easy for the previous detention for investigation to remain unchanged' (Wang Jiancheng 2000:95).

\section{Law as the forum for debates about administrative coercive powers}

What does the story of abolition of detention for investigation tell us about the process of legal reform? This story suggests that the legal forum provides an important framework within which debate about reform of the state's coercive powers may be 
conducted. Although police administrative detention powers were developed in the politically dominated context of social order policy, their reform and restructuring is now being debated in legal terms.

This illustrates the importance of legally-grounded arguments relating to the organisation and justification of police administrative powers. The debate surrounding reform of detention for investigation was fuelled by concerns about its serious and endemic abuse, but also by the inability of the MPS to justify the power in legal terms. The terms of the debate and the ultimate fate of the power were legally framed in terms of the lawfulness of the power, its proper legal characterisation and its place in the legislative regime governing criminal justice. These debates could be seen as implementing the Party's program of administration according to law.

This case illustrates the active engagement of the MPS in the legal debates to define and justify its powers and how such debates can accommodate a range of different voices and positions to a greater extent than would be possible in a more overtly political context, such as the formulation of social order policy. The outcomeabolition of detention for investigation - shows that when the debate about the fate of the power was conducted in legal terms, the police were unable to assert their preferred option. Academics, congress members and permanent employees of the congress were more influential.

Viewed in terms of the emergence of a legal field, these debates about the fate of detention for investigation indicate the development of a specialist language and logic which framed the debate about detention for investigation. It also revealed that the different actors adopted and advocated different positions, though strictly within the boundaries of, and arguably in furtherance of, Party policies favouring administration according to law and the preservation of social order. In contrast to the pre-reform era, with its focus on class struggle, the Party's programs in the reform era are framed in terms that accommodate legitimate disagreement over how Party policy should be interpreted and implemented. The scope of these policies themselves enables the emergence of a field, and permits it a degree of autonomy consistent with the Party's overall agenda for reform. We might argue that the policies of the reform era have permitted a pluralisation of interests and positions that remain consistent with, and in furtherance of, the Party's overall reform agenda.

The emergence of a legitimate sphere within which differing positions may be taken, and a specialist vocabulary in which they are debated, does not guarantee an outcome that better protects citizens' rights. In the case of detention for investigation, though the power was abolished, the power of the public security organs to detain and interrogate criminal suspects was not dramatically reduced, just re-organised.

\section{CONCLUSION}

The process described above may be seen as one of the outcomes of economic reform and modernisation. Party policy has facilitated the emergence of a legal field in which actors, within the constraints of policy, compete to determine the law and 
hence a space in which a proliferation of positions and views can take place. The self-interested nature of these debates facilitates the expansion of legal norms into areas and in relation to powers not previously framed in legal terms, as was the case with detention for investigation. The debates about detention for investigation reveal the emergence of not only a legal vocabulary but also a form of legal logic. Efforts to reform the power reveal the concern of academics at least to improve the internal coherence of the legal system.

It is harder, however, to characterise the reform of this power as part of a transition towards a system of rule of law, as the power of the police to detain has not been substantially constrained, nor, arguably, even made more accountable. By the same token, it is no longer accurate to characterise the law as simply a tool of policy as the scope of policy itself is now susceptible to a range of differing interpretations which are not all necessarily directly controlled by the Party. From this, we might discern that the policy of governance on the basis of law is acquiring a force of its own, not in opposition to Party leadership, but out of it and, at present at least, as a way of implementing Party policies.

\section{NOTES}

1 See Benshu Bianxie Zu (2001); Baum (1994); and Potter (1995), who discuss the state's central role in economic reform.

2 Deng Xiaoping argued that socialist democracy must be 'institutionalised and written into law'. In this speech, Deng set out the blueprint for subsequent legal reform by asserting that the program required that 'there must be laws to go by, laws must be observed and strictly enforced and breaches of the law must be pursued' (Deng 1978:157). See also Central Committee (1978:14).

3 Jiang Zemin's speech, extracted in Liu Hainian (1996:1).

$4 \quad$ Ying Songnian (1992:415) defines yifa xingzheng in formalist terms as follows

1. The administrative department must be established and its powers conferred by law. If the organ or any official acts outside the scope of organisational laws, acts where there is no delegated power, or acts in excess of delegated powers, the act will be void.

2. Administrative acts must not be in conflict with the law and discretionary powers and must be exercised within the scope permitted by law

3. Any act not carried out within the legally specified procedure will be in excess of power and so void.

5 The categories of forces falling within the definition of the people's police (renmin jingcha) are set out in Article 2 of the PRC People's Police Law 1995 (PPL). They include the public security organs (gong'an jiguan), the state security organs (guojia anquan jiguan), the police in prisons (jianyu), RETL management organs (laodong jiaoyang guanli jiguan) and the judicial police (sifa jingcha) of the people's courts and people's procuracy. In this study, all references to 'the police' are to the public security organs.

6 Also translated as 'sheltering for investigation' by Hsia and Zeldin (1992); 'shelter and investigation' by Hecht (1996:21-2), Epstein and Wong (1996:480), Chen Jianfu (1999:201-5) and 'sheltering for examination' by Wong (1996:367).

7 See, for example, Lubman (1995, 1999); Clarke (1985, 1995); Chiu Hongdah (1992); Leng Schaochuan and Chiu Hongdah (1985); Amnesty International (1991, 1992, 1996); Dobinson (2002); Hecht (1996); Turack (1999); Human Rights in China (2001b).

8 In this chapter, the 'reform era' refers to the period after December 1978 when the CPC Central Committee resolved to embark on a program of economic reform and modernisation.

9 These include Lubman (1999); Epstein (1994); Peerenboom (1999, 2002a); Keith (1994); Keith and Lin Zhiqiu (2001); Li (2000); Orts (2001). Peerenboom (1999) draws a distinction between 
'thick' (substantive) and 'thin' (formalist) versions of the rule of law and discusses different versions of the thick theories of the rule of law. Craig (1997:467) distinguishes formalist from substantive versions of the rule of law on the basis that the former is concerned with the manner in which law is promulgated, clarity of the norm and the 'temporal' aspects of the law, whilst the latter is concerned in addition with the content of the law, whether it protects rights and whether the law is considered 'good'.

10 For the purposes of this discussion, I adopt the distinction drawn by Peerenboom (2002b:510), when he distinguishes a 'thin', or formalist version of the rule of law from rule by law on the grounds that the 'former entails meaningful legal limits on the government actors'. This distinction is drawn differently, however, by other scholars such as Orts (2001:94) who defines rule by law in a manner equating to Peerenboom's 'thin' rule of law as 'the use of legal rules in order to assure the uniformity and regularity of an existing legal system'. Orts (2001:94) defines the rule of law as referring 'to a normative and political theory of the relationship of legal institutions and the political state that includes, but is not limited to, a theory of limited government through some form of constitutional separation between the judiciary and other state powers', equating to Peerenboom's 'thick' theory of the rule of law.

11 For a similar analysis, see Lubman (1995); Clarke and Feinerman (1995); H. Tanner (1999); Dobinson (2002); Chen Jianfu (1999). Keith and Lin (2001) on the other hand, argue that amendments to the Criminal Procedure Law and the Criminal Law reflect a changing balance between the instrumental role of law as a tool for social control and law as a mechanism to protect the rights and freedoms of citizens. They subsequently revised this view in light of the state's handling of the 'Falun gong problem' (see Keith and Lin Zhiqiu 2003).

12 More particularly, interpretations of Weber by US sociologists, such as Talcott Parsons, that give universal application to Weber's consideration of the conditions for the emergence of modern capitalism. Parsons argues that societal evolution and modernisation depends on the development of a general legal system that comprises an 'integrated system of universalistic norms' (Parsons 1964:351, 357). Parsons' expanded application of Weber's work is also discussed in Friedman (1969).

13 Ma Yue (1997:113) argues that passage of the People's Police Law in 1995 represented 'the most significant event in China's efforts to create a more professional and modern police force'. Wong (2002:294) asserted that the introduction of a system of police ranks 'regularised, rationalised and legalised the police along Weberian lines', and continued to argue that 'a modern Weberian bureaucracy was in the making, the public security being restructured according to the functional needs of and based on a rational division of labour principle.'

14 Not all scholars are in full agreement with the use of such models to evaluate legal reform. Clarke (2001), for example, criticises as teleological analyses that view the development of the Chinese legal system in terms of how far away it is from a rule of law ideal.

15 Terdiman (1987:806) suggests that this might informally be referred to as a 'legal culture'. I prefer not to adopt this characterisation as it fails to address the extensive literature and divergent views on what constitutes legal culture.

16 Emphasis in original.

${ }_{17}$ These are described by Bourdieu (1987:816-17) as economic, social, cultural, symbolic and juridical capital. Juridical capital is the capacity to define the language in which conflicts are expressed. Bourdieu and Wacquant (1992:98-9) and Johnston and Percy-Smith (2003:323) describe social capital as encompassing personal relationships and the benefits available to individuals as a result of participation in social groups.

18 Although these actors are self interested, this definition suggests that the self-interest is not necessarily narrowly defined. Bourdieu (1990) argues it should not be understood as rational and conscious self-interest.

19 Bourdieu uses the term 'illusio', to designate that each of the actors has their own 'interest' in the game and that they accept the stakes as valuable (Bourdieu and Wacquant 1992:116-7).

20 More specifically, Terdiman (1987:811) explains the term habitus as 'the habitual, patterned ways of understanding, judging and acting which arise from our particular position as members of one or several social "fields", and from our particular trajectory in the social structure'.

${ }^{21}$ See general discussions on this point for example in Potter (2003) and Pei (1995).

22 Goldsmith (1990) also discusses the Australian police as a semi-autonomous social field.

23 Zhengci Falu Jiaoyanshi (1983:4) cites Lenin in support of their proposition that, as an instrument of class rule, the police are an instrument of violence to carry out the dictatorship of the proletariat. 
24 Xi Guoguang and Yu Lei (1996:395-6) refer to the Several Questions Concerning Strengthening and Reform of the Public Security Work adopted at that meeting. Decisions at this meeting included transfer of responsibility for management of Re-education Through Labour (RETL) Camps to the Ministry of Justice (MOJ) and creation of a separate armed police force, the People's Armed Police.

25 In 2002, for example, 50,000 police officers studied for college diplomas; 35,000 studied for tertiary qualifications; 520,000 participated in new recruit training, professional or promotions training; 16,000 economic criminal investigation police sat proficiency tests; and 280,000 police attended skills training programs (Gong'an Bu 2002:65).

26 See, for example, Winkler (1999).

27 State Council Notice Supporting the Unification of the Two Measures of Forced Labour and Detention for Investigation with Re-education through Labour, 29 February 1980.

28 Article 41, Criminal Procedure Law 1979.

29 The Ministry of Public Security's Temporary Regulations on the Management work of Detention for Investigation Centres, 15 February 1984, were passed to 'strengthen and improve the work of detention for investigation centres'. Article 2 states that 'Detention for investigation centres are specialised organs for managing detention for investigation personnel, co-ordinate investigation and protect security'.

30 Under the 1979 Criminal Procedure Law, Article 48, the police could only detain a person for three days prior to making an application for arrest to the procuracy, with a possible extension of up to four days. The procuracy was required to respond within three days. The total possible time for criminal detention was thus ten days. The initial period of detention for investigation, on the other hand, was one month, with possible extensions approved by higher level public security organs of up to a total of three months. Article 3, Ministry of Public Security, Notice on Strictly Controlling the Use of Detention for Investigation Measures, 31 July 1985.

31 Zhang Yu (1993:20) suggests that between 80-90 per cent of people convicted of criminal offences were first detained under this power. Ministry of Public Security, Notice Strictly Prohibiting Public Security Organs from Interfering in Economic Disputes and Illegally Seizing People, 25 April 1992, criticised and prohibited detention by the police of one party to a contract dispute and demanding payment of the amount in dispute to secure their release.

32 The first of which is Ministry of Public Security, Notice on Strictly Controlling the Use of Detention for Investigation, 31 July 1985.

33 Ministry of Public Security, Notice on the Inappropriateness of Publicly Reporting Detention for Investigation, 27 January 1987.

34 These notices included: Ministry of Public Security, Notice on Strengthening the Management Work of Detention Centres and Detention for Investigation Centres, 23 November 1983; Ministry of Public Security, Notice on Strictly Controlling the Use of Detention for Investigation Measures, 31 July 1985; Ministry of Public Security, Notice on Immediately and Conscientiously Rectifying Detention for Investigation Work, 31 July 1986.

35 Ministry of Public Security, Notice on Immediately and Conscientiously Rectifying Detention for Investigation Work, 31 July 1986:381-2.

36 Ministry of Public Security, Notice on the Inappropriateness of Publicly Reporting Detention for Investigation, 27 January 1987.

37 Ministry of Public Security, Notice on Further Controlling the Use of Detention for Investigation Measures, 11 June 1991; Ministry of Public Security, Notice on Urgently Rectifying the Abuse of Detention for Investigation Measures, 15 February 1992; Ministry of Public Security, Notice on Strengthening the Work of Management of the Three Detention [Centres] and Putting an End to Situations where Detainees get Beaten to Death, 22 April 1993; Ministry of Public Security, Notice Strictly Prohibiting Public Security Organs from Interfering in Economic Disputes and Illegally Seizing People, 25 April 1992.

38 Ministry of Public Security, Notice on Further Controlling the Use of Detention for Investigation Measures, 11 June 1991. Yang Xinhua (1991) reports on an inquiry into enforcement practices made by the Internal Affairs and Judicial Work Committee in 1990, which noted systematic abuse of detention for investigation. Ministry of Public Security, Notice on Urgently Rectifying the Abuse of Detention for Investigation Measures, 15 February 1992, refers to an investigation carried out by the Office of the Law Committee of the NPC and the Legislative Affairs Committee of the Standing Committee in December 1991 into abuses of detention for investigation. 
39 Article 2 provides that

[t]hose people who have committed minor criminal offences and do not tell their name and address and whose background is not clear, or they have committed a minor criminal offence and are suspected of floating from place to place committing crime, committing multiple crimes or forming a group to commit crime, who need to be taken in to investigate their criminal acts, should be sent to a specially formed unit in RETL camps to carry out investigation...In general where the danger would not be great if they were placed in society, can be placed under house arrest, or released on bail etc in accordance with the provisions of the CPL whilst carrying out investigation.

40 One argument was that it was beyond the power of the State Council to regulate detention powers, discussed below.

41 The process was commenced but never completed because it was overshadowed by the hard strike law and order campaign that started in August 1983 (Gao Xianduan 1990) and the transfer in May 1983 of responsibility for management of RETL camps from the Ministry of Public Security to the Ministry of Justice (Luo Feng 1992; Xia Chongsu 2001).

42 Passed by the NPC Standing Committee on 5 September 1986 and amended 12 May 1994.

43 Guo Dawei (1990:28) argues that the 'only way out' to preserve the existence of the power was for the NPC to pass legislation, to use legal means to regularise its existence. The Ministry of Public Security's Notice on Several Questions about the Implementation of the 'Administrative Litigation Law' by Public Security Organs, 30 October 1990, set out the rules that were to constitute the legal basis of the power.

4. Article 11(1)(i) enables those who are dissatisfied with an administrative punishment such as detention, imposition of a fine, revocation of a permit or licence, an order to suspend production of business activities or the confiscation of property to commence an action. This paragraph includes punishments such as administrative detention under the Security Administrative Punishment Regulations.

45 Article 11(1)(ii) of the Administrative Litigation Law enables the court to accept complaints about, among other things, the lawfulness of measures taken to restrict or deprive freedom of the person.

46. Articles 32, 52 and 53, Administrative Litigation Law.

47 Discussed and passed at the 499th meeting of the Adjudication Committee of the Supreme People's Court on 29 May 1991, reproduced in Huang Jie (1993:659).

48 Article 2, Opinion of the Supreme People's Court Concerning Several Questions on the Implementation of the 'PRC Administrative Litigation Law'.

49 Reproduced in Huang (1993:668). Point 3 of the Notice provides that [u]ntil the new detention for investigation legislation is published, the targets of detention for investigation can be determined according to the provisions of the 1980 Notice of the State Council on the Unification of the Two Measures of Forced Labour and Detention for Investigation with Reeducation through Labour, which was promulgated in the (1980) No.2 Gazette of the State Council. Investigation and approval procedures and the time limits for detention for investigation must be implemented according to the provisions of the 1985 Ministry of Public Security Notice on Strictly Controlling the Use of Detention for Investigation Measures. In handling specific detention for investigation cases you must incorporate the Ministry of Public Security Notice Printing and Distributing the 'Summary of the Minutes of Meeting of National Public Security Legal System Work' of May this year, know it well and handle matters strictly according to its spirit. Each level public security organ must strictly eliminate the wanton expansion the scope of detention for investigation, exceeding the time limits, taking people into detention etc, such illegal phenomena.

50 Hsia and Zeldin (1992) list articles published between 1987 and 1991.

51 Hecht (1996) suggests that organised academic discussions on revision of the Criminal Procedure Law commenced in late 1991.

52 Cui is professor in the Chinese People's Public Security University. See also Wang Xixin (1993); Zhang Jianwei and Li Zhongcheng (1994).

53 Cui Ming (1993b) cited arguments that the power to pass laws authorising detention was outside the scope of Article 89 of the Constitution, which sets out the powers of the State 
Council. Cai Dingjian (1991) asserts that only the NPC or its Standing Committee has the power to pass laws that restrict personal freedom.

${ }_{54}$ Cui Ming (1993b) cites leadership of public security organs and government at different levels as the main proponents of its retention

$55 \quad$ Fan Chongyi and Xiao Shengxi (1991) argued the power should be incorporated into the revised Criminal Procedure Law. Song Qian (1992) and Chen Weidong and Zhang Tao (1992b) argued it should not.

56 Mao Zhibin (1991); Zhang Shanyu and Zhang Shuyi (1991); Chen Weidong and Zhang Tao (1992a, 1993) argue that the power is administrative and should not be abolished. Wang Xixin (1993), however, argues that the power is substantively criminal in nature and should be abolished.

57 Passed by the National People's Congress on 4 April 1989.

58 Ministry of Public Security, Notice on Several Questions on the Implementation of the Administrative Litigation Law by Public Security Organs, 30 October 1990, at point 3 discusses the documents that are to form the normative legal basis for reviewing the legality of determinations to impose detention for investigation.

59 The requirement for arrest in Article 40 of the 1979 Criminal Procedure Law was that 'the principal facts of the crime have been clarified and [the defendant] could be sentenced to a punishment of not less than imprisonment'.

60 Article 48, Criminal Procedure Law 1979. The maximum time for detention was three days, with a possible extension of up to four days. The procuracy was required to approve or reject the application within three days of receipt of the application. Article 96, Draft Criminal Procedure Law; Chen and Yan (1995).

61 The unpublished Ministry of Public Security document is entitled Plan for Specific Revision of Provisions of the CPL Relevant to the Public Security Organs (Draft Soliciting Opinions).

62 Proposed amendment to Criminal Procedure Law 1979 Article 40 to enable arrest where 'there is evidence to show a criminal acts or suspicion of a crime, where it is necessary to pursue criminal responsibility...', Plan for Specific Revision of Provisions of the CPL Relevant to the Public Security Organs (Draft Soliciting Opinions).

63 Specifically, amendments to Criminal Procedure Law 1979 Article 41 to include those suspected of committing crime, who do not tell their true name and address and whose status is unclear, those who have committed a minor crime, who are suspected of going from place to place committing crime, and those who have committed a minor crime who are strongly suspected of committing many crimes or committing crimes in a gang. Plan for Specific Revision of Provisions of the CPL Relevant to the Public Security Organs (Draft Soliciting Opinions). See also the proposal that Article 48 of the Criminal Procedure Law 1979 be revised to extend the time limits for applying for arrest to seven days and for a possible extension of between five and 10 days 'where there is a serious suspicion that they have gone from place to place committing crimes, committed many crimes or committed crimes in a gang, where the facts are complicated'.

${ }_{64}$ The proposal would amend Article 48 of the Criminal Procedure Law 1979. See Plan for Specific Revision of Provisions of the CPL Relevant to the Public Security Organs (Draft Soliciting Opinions).

65 Article 60, Criminal Procedure Law.

66 Article 61(7), Criminal Procedure Law.

67 Article 69(2), Criminal Procedure Law refers to 'Major suspects who are on the run, who repeatedly commit crime, or who gang up with others to commit crime.'

${ }_{68}$ Article 69, Criminal Procedure Law. This category of person can be held for 30 days before the public security organ is required to apply for arrest. The people's procuracy is required either to approve or reject the request for arrest within seven days of receipt.

${ }_{69}$ See Hecht (1996) and Human Rights in China (2001a) on the difficulties in reforming the Criminal Procedure Law. Fu Hualing (1998) discusses access of an accused person in detention to a lawyer. H. Tanner (1999) considers that in the 1980s many enforcement problems were due in part to problems of poor payment and lack of training.

to Ministry of Public Security, Regulations on the Procedures for Handling Criminal Cases, passed on 20 April 1998. 


\section{REFERENCES}

Alford, W., 1999. 'A second Great Wall? China's post-Cultural Revolution project of legal construction', Cultural Dynamics, 11(3):193-212.

Amnesty International, 1991. China: punishment without crime, Amnesty International, London.

, 1992. Detention Without Trial: a system for extra-judicial punishment, Amnesty International, London:10-13.

_ 1996. China: no-one is safe - political repression and abuse of power in the 1990s, Amnesty International, London.

Bakken, B., 1993. 'Crime, juvenile delinquency and deterrence policy in China', Australian Journal of Chinese Affairs, 30(3):29-58.

—, 2000. The Exemplary Society, Human Improvement, Social Control and the Dangers of Modernity in China, Oxford University Press, New York.

Baum, R., 1986. 'Modernization and legal reform in post-Mao China: the rebirth of socialist legality', Studies in Comparative Communism, 19(2):69-103.

—, 1994. Burying Mao: Chinese politics in the age of Deng Xiaoping, Princeton University Press, Princeton.

Benshu Bianxie Zu, (Book Editorial Committee) (ed.), 2001. Zhongguo Gongchandang Bashi Nian Xuexi Duben [Reader on 80 Years of the Chinese Communist Party], Zhonggong Zhongyang Dangxiao Chubanshe [Central Party School Press], Beijing.

Bourdieu, P., 1987. 'The force of law: toward a sociology of the juridical field', Hastings Law Journal, 38(5):814-54 [tr. R. Terdiman].

—, 1990. In Other Words: essays towards a reflexive sociology, Polity Press, Cambridge.

— and Wacquant, L., 1992. An Invitation to Reflexive Sociology, University of Chicago Press, Chicago.

Boxer, J.T., 1999. 'China's death penalty: undermining legal reform and threatening the national economic interest', Suffolk Transnational Law Review, Summer:593-618.

Brugger, B. and Reglar, S., 1994. Politics, Economy and Society in Contemporary China, MacMillan Press, Hong Kong.

Cai, Dingjian, 1991. 'Guojia Quanli Jiexian Lun [Discussion of the limits of state power]', Zhongguo Faxue [Chinese Legal Science], 2:54-61.

Central Committee, 1961. Report on Urgently Preventing the Free Movement of the Population, Central Committee of the Communist Party of China, Beijing, 7 November.

— 1957. Instruction on Preventing the Blind Outflowing of People from Rural Areas, Central Committee of the State Council, Beijing, 18 December.

- 1978. Communique of the Third Plenary Session of the 11th Central Committee of the Communist Party of China, 22 December, Central Committee, Beijing:6-16.

- 1983. Notice Approving and Issuing the Two Documents of the National Public Security Work Meeting, Central Committee, Communist Party or China, Beijing, 28 May. 
Chen, Guangzhong and Yan, Duan (eds), 1995. Zhonghua Renmin Gongheguo Xingshi Susong Fa Xiugai Jianyi yu Lunzheng [Preliminary Version for Revision of the 'Criminal Procedure Law of the People's Republic of China' and its Annotations], Zhongguo Fangzheng Chubanshe, Beijing.

Chen, Jianfu, 1999. Chinese Law: towards an understanding of Chinese law, its nature and development, Kluwer Law International, The Hague.

Chen, Weidong and Zhang, Tao, 1993. 'Zai Tan Shourong Shencha Buyi Feichu [Another discussion of why detention for investigation should not be abolished]', Zhongguo Faxue [Chinese Legal Science], 3:113-14.

—, 1992a. 'Shourong Shencha de Ruogan Wenti Yanjiu [An examination of several questions about detention for investigation]', Zhongguo Faxue [Chinese Legal Science], 13:82-87.

__, 1992b. "Shourong Shencha Ruogan Wenti Yanjiu [Research on several questions about detention for investigation]' in Zhongguo Faxue Hui Susong Fa Yanjiu Hui [Procedure Law Association of the China Law Society] (eds), Xingshi Susong Fa de Xuigai yu Wanshan [Revision and perfection of the Criminal Procedure Law], Zhongguo Zhengfa Daxue Chubanshe [China University of Politics and Law Press], Beijing:170-78.

Chiu, Hongdah, 1992. 'China's criminal justice system and the trial of pro-democracy dissidents', New York University Journal of International Law and Politics, 24(3):1181201.

Chu, M., 2001. 'Criminal procedure reform in the People's Republic of China: the dilemma of crime control and regime legitimacy' , UCLA Pacific Basin Law Journal, 18(2):157-208.

Clarke, D.C., 2001. 'Puzzling observations in Chinese law: when is a riddle just a mistake?', Social Science Research Network, available online at http:/ / ssrn.com/ abstract $=293627$.

Clarke, D., 1985. 'Concepts of law in the Chinese anti-crime campaign', Harvard Law Review, 98(8):1890-908.

— 1995. 'Justice and the legal system in China' in R. Benewick and P. Wingrove (eds), China in the 1990s, Macmillan, London:83-93.

— and Feinerman, J., 1995. 'Antagonistic contradictions: criminal law and human rights in China', The China Quarterly, 141:135-54.

Conner, A., 2000. 'True confessions? Chinese confessions then and now' in K.G. Turner, J.V. Feinerman and R.K. Guy (eds), The Limits of the Rule of Law in China, University of Washington Press, Seattle:132-62.

Craig, P., 1997. 'Formal and substantive conceptions of the rule of law: an analytical framework', Public Law:467-87.

Cui, Ming, 1993a. 'Shehui Zhuyi Chuji Jieduan yu Gong'an Jianshe [Preliminary stages of socialism and public security construction]' in Cui Ming (ed.), Zhongguo Dangdai Xing yu Fa [China's Contemporary Crime and Law], Qunzhong Chubanshe, Beijing:353-57. 
1993b. 'Shourong Shencha de Lishi, Xianzhuang Yu Chulu [The history, present situation and prospects of detention for investigation]' in Cui Ming (ed.), Zhongguo Dangdai Xing Yu Fa [China's Contemporary Crime and Law], Qunzhong Chubanshe, Bejing:90-98.

Cui, Xin, 1996. 'Xingshi Susong Fa Xiugai Hou Gong'an Gongzuo Mianling de Xingshi Ji Renwu [The situation and tasks of public security work after revision of the Criminal Procedure Law]', Gong'an Yanjiu [Public Security Studies], 3:31, 36-38.

Curran, D. and Cook, S., 1993. 'Growing fears, rising crime: juveniles and China's justice system', Crime and Delinquency, Special Issue: crime and justice in China and Japan, 39(3):296-315.

Deng, Xiaoping, 1978. 'Emancipate the mind, seek truth from facts and unite as one in looking to the future' in Bureau for the Compilation and Translation of Works of Marx, Lenin, Engels and Stalin under the Central Committee of the Communist Party of China (ed.), Selected Works of Deng Xiaoping (1975-1982), Volume 2, Foreign Languages Press, Beijing:151-65.

Dobinson, I., 2002. 'The Criminal Law of the People's Republic of China (1997): real change or rhetoric?', Pacific Rim Law and Policy Journal, 11(January):1-62.

Dowdle, M., 1997. 'The constitutional development and operations of the National People's Congress', Columbia Journal of Asian Law, 11(1):1-125.

_ 1999. 'Heretical laments: China and the fallacies of "rule of law"', Cultural Dynamics, 11(3):287-314.

Dreyer, J., 1996. China's political system: modernization and tradition, Allyn and Bacon, Boston.

Dutton, M., 1992a. 'Disciplinary projects and carceral spread: Foucauldian theory and Chinese practice', Economy and Society, 21(2):276-94.

_ 1992b. 'A mass line without politics, community policing and economic reform' in A. Watson (ed.), Economic Reform and Social Change in China, Routledge, London:200-27.

, 1995. 'Dreaming of better times: "repetition with a difference" and community policing in China', Positions: East Asia Cultures Critique, 3:415-47.

— 2000. 'The end of the (mass) line? Chinese policing in the era of contract', Social Justice, 27(2):61-105.

— and Lee, Tianfu, 1993. 'Missing the target? Policing strategies in the period of economic reform', Crime and Delinquency, Special Issue: Crime and Justice in China and Japan, 39(3):316-36.

Epstein, E., 1994. 'Law and legitimation in post-Mao China' in P. Potter (ed.), Domestic Law Reforms in Post-Mao China, M.E. Sharpe, Armonk:19-55.

— and Wong, S. Hing-Yan, 1996. "The concept of "dangerousness" in the People's Republic of China and its impact on the treatment of prisoners', British Journal of Criminology, 36(4):472-97.

Fan, Chongyi and Xiao, Shengxi (eds), 1991. Xingshi Susong Fa Yanjiu Zongshu Yu Pingija [Summary and Appraisal of Criminal Procedure Law Study], Zhongguo Zhengfa Daxue Chubanshe, Beijing. 
Feinerman, J., 1994. 'Legal institution, administrative device, or foreign import: the roles of contract in the People's Republic of China' in P. Potter (ed.), Domestic Law Reforms in Post-Mao China, M.E.Sharpe, New York:225-44.

Forster, K., 1985. 'The 1982 campaign against economic crime in China', Australian Journal of Chinese Affairs, 14:1-19.

Friedman, L., 1969. 'On legal development', Rutgers Law Review, 24(1):11-64.

$\mathrm{Fu}$, Hualing, 1994. 'A bird in the cage: police and political leadership in post-Mao China', Policing and Society, 4:277-91.

-1998. 'Criminal defence in China: the possible impact of the 1996 Criminal Procedure Law reform', China Quarterly, 153(March):31-48.

Gai, Jun (ed.), 2001. Zhongguo Gongchandang 80 Nian Lishi Jianbian [A Short History of the 80 Years of the Chinese Communist Party], Zhonggong Zhongyang Dangxiao Chubanshe, Beijing.

Gao, Chuanli, 1998. 'Xuexi Yifa Zhiguo Jianshe Shihui Zhuyi Fazhi Guojia Jiben Fanglue: Tuidong Shiwu Da Jingshen de Guanche Luoshi [Study ruling the country by law to construct the basic plan for ruling the country by law: promote implementation of the spirit of the Fifteenth Central Committee]' in Sifabu Sifa Yanjiu Suo [Judicial Research Office of the Bureau of Justice] (ed.), Yifa Zhiguo Jiben Fanlue Lunwenji [Collection of Essays on the Basic Plan for Ruling the Country by Law], Falu Chubanshe, Beijing:1-16.

Gao, Xianduan, 1990. 'Shourong Shencha de Wenti yu Chulu [The Problem and Prospects for Detention for Investigation]' Gong'an Yanjiu [Public Security Studies], 3:18-21.

Ge, Fei, 1998. 'Second class citizen: a record of China's first "severe strike" campaign' in M. Dutton (ed.), Streetlife China, Cambridge University Press, Cambridge:65-69.

Goldsmith, A., 1990. 'Taking police culture seriously: police discretion and the limits of law', Policing and Society, 1:91-114.

Gong'an Bu [Ministry of Public Security], 2002. Zhongguo Gong'an Gongzuo [Policing in China], Gong' an Bu, Beijing:1-90.

Gu, Haiwen, 1992. 'Gong'an Jiguan dui Bupi Bo de Dangshiren you Xingju zhuan Shoushen Chuyi [My humble opinion on public security organs transferring criminal detainees to shelter and investigation when arrest has not been approved]', Fanzui yu Duice [Crime and Countermeasures], 4:56-7.

Guo, Dawei, 1990. 'Zuohao Shishi Xingzheng Susong Fa de Zhunbei Baozheng Gong'an Jiguan Yifa Xingzheng [Do a Good Job of Preparation for Implementation of the Administrative Litigation Law to Ensure Public Security Organs Carry out Administration according to Law]', Gong'an Yanjiu [Public Security Studies], 1:27-29.

Hecht, J., 1996. Opening to Reform? An analysis of China's revised Criminal Procedure Law, Lawyers' Committee for Human Rights, New York,

Hsia, Tao Tai and Zeldin, W., 1992. 'Sheltering for examination [Shourong Shencha] in the legal system of the People's Republic of China', China Law Reporter, 7(2):97128. 
Huang, Jie (ed.), 1993. Xingzheng Susong Shiyong Daquan [Encyclopedia of Administrative Litigation], Hebei Renmin Chubanshe, Heibei.

Human Rights in China, 2001a. Empty Promises: human rights protection and China's Criminal Procedure Law in practice, Human Rights in China, New York:1-94.

— 2001b. Re-education through labour (RTL): a summary of regulatory issues and concerns, Human Rights in China, Hong Kong.

Jiang, Bo and Zhan, Zhongle, 1994. Gong'an Xingzheng Fa [Public Security Administrative Law], Zhongguo Renshi Chubanshe [China Personnel Press], Beijing.

Johnston, G. and Percy-Smith, J., 2003. 'In search of social capital', Policy and Politics, 31:321-34.

Jones, W., 1979. 'On the campaign trail in China', Review of Socialist Law, 5(4):457-62.

Keith, R., 1994. China's Struggle for the Rule of Law, St Martin's Press, New York. and Lin, Zhiqiu, 2001. Law and Justice in China's Marketplace, Palgrave, New York.

_ 2003. "The "Falungong Problem": politics and the struggle for the rule of law in China', China Quarterly, 175:623-42.

Leng, Shaochuan and Chiu, Hongdah, 1985. Criminal Justice in Post-Mao China: analysis and documents, University of New York Press, Albany.

Li, Huayin and Liu, Baiyang (eds), 1992. Gong'an Xingzheng Chengxu Yu Zingzheng Susong [Public Security Administrative Procedure and Administrative Litigation], Qunzhong Chubanshe, Beijing.

Li, Linda Chelan, 2000. "The "rule of law" policy in Guangdong: continuity or departure? Meaning, significance and processes", China Quarterly, 161:199-220.

Lieberthal, K., 1995. Governing China From Revolution Through Reform, W.W. Norton and Company, New York.

Liu, Hainian, 1996. 'Qian Yan [Forward]' in Wang Jiafu, Liu Hainian, Li Buyun and Li Lin (eds), Yifa Zhiguo Jianshe Shehui Zhuyi Fazhi Guojia [Ruling the Country According to Law, Establishing a Socialist Nation Ruled according to Law], China Legal System Press, Beijing:1-4.

— and Liu, Baiyang (eds), 1992. Gong'an Xingzheng Chengxu yu Xingzheng Susong [Public Security Administrative Procedure and Administrative Litigation], Qunzhong Chubanshe, Beijing.

Liu, Shipu, 1990. 'Guanyu Shourong Shencha de Sikao [Reflections on detention for investigation]', Gong'an Yanjiu [Public Security Studies], 5:22-26.

Lo, Carlos Wing-Hung, 1997. 'Socialist legal theory in Deng Xiaoping's China', Columbia Journal of Asian Law, 11(2):469-486.

Lubman, S., 1995. 'Introduction: the future of Chinese law', China Quarterly, 141:1-21.

_ 1999. Bird in a Cage: legal reform in China after Mao, Stanford University Press, Stanford. 
Luo, Feng, 1992. 'Laodong Jiaoyang Shenpi Gongzuo de Huigu yu Sikao [Retrospect and thoughts on investigation and approval of re-education through labour]', Gong'an Yanjiu [Public Security Studies ], 5:33-37.

Ma, Yue, 1997. 'The Police Law 1995: organization, functions powers and accountability of the Chinese Police', Policing: an international journal of police strategies and management, 20(1):113-35.

Mao, Zhibin, 1991. 'Shourong Shencha shi Xingzheng Qiangzhi Cuoshi [Shelter and investigation is an administrative coercive measure]', Gong'an Daxue Xuebao [Journal of the Public Security University], 5:13-14.

Munro, R., 2000. 'Judicial psychiatry in China and its political abuses', Columbia Journal of Asian Law, 14(1):1-128.

Orts, E., 2001. 'The rule of law in China', Vanderbilt Journal of Transnational Law, 34(1):43-115.

Parsons, T., 1964. 'Evolutionary universals in society', American Sociological Review, 29:339-57.

Peerenboom, R., 1999. 'Ruling the country in accordance with law: reflection on the rule and role of law in contemporary China', Cultural Dynamics, 11(3):315-51.

_ 2002a. China's Long March toward Rule of Law, Cambridge University Press, Cambridge.

— 2002b. 'Let one hundred flowers bloom, one hundred schools contend: debating rule of law in China', Michigan Journal of International Law, 23(3):471-544.

Pei, Minxin, 1995. '“Creeping democratisation" in China', Journal of Democracy, 6(4):65-79.

Peng, Zhen, 1982. 'Xin Shiqi de Zhengfa Gongzuo [Political-legal work in the new era)' in Lun Xin Zhongguo de Zhengfa Gongzuo [Discussion of the Political Legal Work in New China], Zhongyang Wenzhai Chubanshe, Beijing:282-91.

Potter, P., 1995. 'Foreign investment law in the People's Republic of China: dilemmas of state control', China Quarterly, 141(March):155-85.

_ 1999. 'The Chinese legal system: continuing commitment to the primacy of state power', China Quarterly, 159(September):673-83.

_ 2003. 'Globalization and economic regulation in China: selective adaptation of globalized norms and practices', Washington University Global Studies Law Review, 2(1):119-50.

Shen, Yuan Yuan, 2000. 'Conceptions and receptions of legality: understanding the complexity of law reform in modern China' in K.G. Turner, J.V. Feinerman and R.K. Guy (eds), The Limits of the Rule of Law in China, University of Washington Press, Seattle:20-44.

Shen, Zhongmin and Xu, Zhenqiang, 1997. 'Lun Zhongguo Jingcha Jiaoyu de Fazhan Zouxiang [Discussing trends in the development of China's police education]' in Kang Damin (ed.), Lun Zhongguo Tese de Gong'an [Discussion of Public Security with Chinese Characteristics], Qunzhong Chubanshe, Beijing:138-56. 
Shih, Chih-yu, 1999. Collective Democracy, Political and Legal Reform in China, The Chinese University Press, Hong Kong.

Situ, Yingyi and Liu, Weizhang, 1996. 'Comprehensive treatment to social order: a Chinese approach against crime', International Journal of Comparative and Applied Criminal Justice, 20(1):95-115.

Song, Qiang, 1992. 'Lun Woguo Xingshi Qiangzhi Cuoshi Xin Tixi [Discussing the new system of China's criminal coercive measures]' in Zhongguo Faxue Hui Susong Fa Yanjiu Hui [Procedure Law Association of the China Law Society] (ed.), Xingshi Susong Fa de Xuigai yu Wanshan [Revision and Perfection of the Criminal Procedure Law], Zhongguo Zhengfa Daxue Chubanshe, Beijing:136-45.

Spence, J., 1990. The Search for Modern China, W.W. Norton and Company, New York and London.

State Council, 1975a. Report of the National Meeting on the work of Public Order on Railways, State Council, Communist Party or China, Beijing.

_ 1975b. Notice on doing a good job of Ferreting out Floating Criminals during the New Year and Spring Festival Period, State Council, Communist Party of China, Beijing.

Tanner, H., 1994. Crime and Punishment in China, 1979-89, PhD Thesis, Columbia University, New York.

- 1995. 'Policing, punishment and the individual: criminal justice in China', Law and Social Inquiry, 20(1):277-303.

__ 1999. Strike Hard! Anti-crime campaigns and Chinese criminal justice, 1979-85, Cornell University, Ithaca.

Tanner, M.S., 1999. 'Ideological struggle over police reform, 1988-1993' in E.A. Winkler (ed.), Transition from Communism in China: institutional and comparative analyses, Lynne Rienner, London:111-28.

— 2000 . 'State coercion and the balance of awe: the 1983-1986 "Stern Blows" anti-crime campaign', China Journal, 44(July):93-125.

Terdiman, R., 1987. 'Translator's Introduction: the force of law-Toward a sociology of the juridical field', Hastings Law Journal, 38(5):805-13.

Trubek, D., Dezalay, Y., Buchanan, R. and Davis, J., 1994. 'Global restructuring and the law: studies of the internationalization of legal fields and the creation of transnational arenas', Case Western Reserve Law Review, 44(2):407-98.

Turack, D., 1999. 'The new Chinese criminal justice system', Cardozo Journal of International and Comparative Law, 7(1):49-72.

von Senger, H., 1985. 'Recent developments in the relations between state and party norms in the People's Republic of China' in S.R. Schram (ed.), The Scope of Power in China, The Chinese University Press, Hong Kong:171-207.

Wang, Fang (ed.), 1993. Mao Zedong Gong'an Gongzuo Lilun [Mao Zedong Public Security Work Theory], Qunzhong Chubanshe, Beijing. 
Wang, Jiancheng, 1992. 'Shourong Shencha Chulu Hezai [Where lies the way out for detention for investigation?]' in Zhongguo Faxue Hui Susong Fa Yanjiu Hui, [Procedure Law Association of the China Law Society] (ed.), Xingshi Susong Fa de Xuigai yu Wanshan [Revision and Perfection of the Criminal Procedure Law], Zhongguo Zhengfa Daxue Chubanshe, Beijing:179-86.

, 2000. 'Qiangzhi Cuoshi [Coercive Measures]' in Chen Guangzhong (ed.), Xingshi Susongfa Shishe Wenti Yanjiu [Research on the Issues in Implementation of the Criminal Procedure Law], Zhongguo Falu Chubanshe, Beijing:78-99.

Wang, Xixin, 1993. 'Shourong Shencha Zhidu Ying yu Feichu [The System of detention for investigation should be abolished]', Zhongguo Faxue, 3:110-12.

Ward, R. and Bracey, D., 1985. 'Police training and professionalism in the People's Republic of China', The Police Chief, 5(52):36-38.

Webb, J., Schirato, T. and Danaher, G., 2002. Understanding Bourdieu, Sage Publications, London.

White, L.T., 1999. Unstately Power: Local Causes of China's Intellectual, Legal and Governmental Reforms, M.E. Sharpe, London.

Winkler, E.A., 1999. 'Describing Leninist Transitions' in E.A. Winkler (ed.), Transition from Communism in China: institutional and comparative analyses, Lynne Rienner, London:3-48.

Wong, Kam, 1996. 'Police Powers and Control in the People's Republic of China: The History of Shoushen', Columbia Journal of Asian Law, 10(2):367-390.

— 2002. 'Policing in the People's Republic of China: the road to reform in the 1990s', British Journal of Criminology, 42(2):281-316.

Xi, Guoguang and Yu, Lei (eds), 1996. Zhongguo Renmin Shigao [Draft History of the Chinese People's Public Security], Jingguan Jiaoyu Chubanshe, Beijing.

Xia, Chongsu (ed.), 2001. Laodong Jiaoyang Zhidu Gaige Wenti Yanjiu [Research on the Reform of Re-education Through Labour], Falu Chubanshe, Beijing.

Yang, Xinhua, 1991. 'Shourong Shencha Cunzai de Wenti Ji Duice [Problems and strategies of the existence of detention for investigation]', Jiangxi Faxue [Jiangxi Legal Studies], 4:42.

Ying, Songnian (ed.), 1992. Xingzheng Fa yu Xingzheng Susong Fa Cidian [Dictionary of Administrative Law and Administrative Litigation Law], Zhongguo Zhengfa Daxue Chubanshe, Beijing.

Zhang, Jianwei and Li, Zhongcheng, 1994. 'Lun Feichu Shourong Shencha [Discussing the abolition of detention for investigation]', Zhongwai Faxue, 3:55-59.

Zhang, Qingwu, 1990. 'Hukou Qianyi Zhengce Yanjiu [Study of Household Registration Migration Policy]', Gong'an Yanjiu [Public Security Studies], 1:35-37.

Zhang, Shanyu and Zhang, Shuyi (eds.), 1991. Zouchu Digu de Zhongguo Xingzheng Faxue -Zhongguo Xingzheng Faxue Zongshu Yu Pingjia [The Under-estimated Chinese Administrative Law Studies: summary and review of China's Administrative Law Studies], Zhongguo Zhengfa Daxue Chubanshe, Beijing. 
Zhang, Xu, 1993. 'Lun Shoushen de Chulu yu Daibu de Gaige [Discussing the way out for Detention for Investigation and Reform of Arrest]', Xiandai Faxue [Modern Legal Science], 2:20.

Zhengci Falu Jiaoyanshi [Politics and Law Teaching and Research Office] (ed.), 1983. Gong'an Gongzuo Gailun [Introduction to Public Security Work], Zhongguo Xingshi Jingcha Xueyuan Chubanshe, Beijing.

Zhongguo Faxue Hui Susong Fa Yanjiu Hui [Procedure Law Association of the China Law Society] (ed.), 1992. Xingshi Susongfa de Xiugai yu Wanshan [Revision and Perfection of the Criminal Procedure Law], Zhongguo Zhengfa Daxue Chubanshe, Beijing.

Zhu, Rongji, 1999. 'Renzhen Guanche Yifa Zhiguo Fanglue Qieshi Quanmian Tuijin Yifa Xingzheng [Diligently implementing the General Plan of Ruling the Country According to Law is to conscientiously and comprehensively advance administration according to law]' in Guowuyuan Yifaxingzheng Gongzuo Huiyi [State Council Administration According to the Law Working Committee] (ed.), Yifa Xingzheng, Congyan Zhizheng, Jianshi Lianjie, Qinzheng, Wushi, Gaoxiao Zhengfu [Administration According to Law, Strictly Establish an Honest, Industrious, Pragmatic and Highly Efficient Government], Zhongguo Fazhi Chuanshe, Beijing:1-12. 